\title{
The 1960s Modernization Theory Updated: The Role of the Evaluative State in Today's Brazilian Education
}

\author{
Flávia Magalhães Freire ${ }^{1, *}$, Daniela da Costa Britto Pereira Lima ${ }^{2}$ \\ ${ }^{1}$ Education, Federal University of Goiás, Brazil \\ ${ }^{2}$ Public Policy, Strategy and Development, Federal University of Goiás, Brazil
}

Copyright $(\mathrm{C} 2018$ by authors, all rights reserved. Authors agree that this article remains permanently open access under the terms of the Creative Commons Attribution License 4.0 International License

\begin{abstract}
The present paper aims to analyze the trajectory of the Walt Whitman Rostow's modernization theory (1960), the theoretical foundation of the Alliance for Progress, as well as the unfolding of this theory in what Afonso [1] names as the Evaluative State in education. This paper draws upon the works of Afonso [1]; Dale [12]; Gaio [9]; Latham [4]; Loureiro [6]; Neto [11]; Rabe [13]; Ribeiro [7]; Romanelli [8]; Saviani [10] and the official documents of the American government [2]. The literature review and the documental research demonstrate that there is a close tie between the modernization theory's core values and the current international standardized tests, such as the PISA (OECD Program for International Student Assessment), which aim to rank and classify the countries' educational systems according to universal values.
\end{abstract}

Keywords Alliance for Progress, Modernization Theory, Educational Development, Evaluative-state

\section{Introduction}

The Alliance for Progress emerged in the 1960s, aiming to strengthen the ties between the United States and Latin America. The modernization theory, elaborated by political scientist Walt Whitman Rostow, supported the Alliance ideologically.

This theory's premise is the establishment of an ideal of the modernized nation, setting universal standards of economic, social and cultural development to all countries. Countries whose societies differ from these standards should follow a path to modernization to accomplish the ideal model of nation-state. The United States government of the time would aid in this development process, providing financial support and technical assistance.

Even though the modernization theory may be considered outdated by many thinkers nowadays, Afonso ${ }^{[1]}$ argues that the theory's core premise perpetuates in today's Evaluative State model. More specifically, the updated version of the theory reveal itself in the diffusion of international norms to measure and classify a wide range of national educational systems across the globe. The resulting performance in the standardized tests and rankings allegedly reflects the current level of development/modernization of the participating countries.

In this paper, we aim to reflect on the modernization theory's trajectory as well as to understand its potential role in today's education. Our literature review is based on the following authors: Afonso [1], Dale [12], Gaio [9], Latham [4], Loureiro [6], Neto [11], Rabe [3], Ribeiro [7], Romanelli [8], and Saviani [10]. As for the documentary research, we draw on the 1960s United States government official documents [2] on the Alliance for Progress. The paper is divided into five sections: 1) Introduction; 2) The 1960s Modernization Theory: context and premises; 3) The role of the Modernization Theory in the shaping of the 1960s Brazilian public policies for economic, social and educational development; 4) The Modernization Theory updated: the role of the Evaluative State in today's education; 5) Conclusion.

The methodology of the article proposes to be, mainly, a review of literature with comparison of theories, with the objective to analyze the Modernization Theory, by Walt Whitman Rostow, elaborated and put into practice in the 1960s. Through Afonso [1], we will analyze international educational programs to try to understand how Rostow's theory, which many believe is obsolete, still persists on the world stage. The phases of the research will be initially, the reading of the authors indicated in the previous paragraph. After that there will be a debate and comparison about the ideas studied, seeking to find indications of the Modernization Theory. Finally, the results will be exposed at the conclusion.

\section{The 1960s Modernization Theory: Context and Premises}

The Modernization Theory emerged in the 1960s, 
motivated by the United States government need for an ideological basis to support the Alliance for Progress, the new US policy towards Latin America. Some Cold War (1947-1991) heightened tension events, such as the ousting of the Cuban President Fulgencio Batista and the resulting Cuban Revolution (1959) as well as the failed military invasion of the Bay of Pigs (1961), led the US government to rethink its policy towards Latin America. Mostly, these events demonstrated the need for a policy that would disseminate the US' own ideology in Latin America to counter the spreading of the Soviet Union communism, the main supporter of the Cuban Revolution [2].

The formulation of such a policy, one that would counter the communist ideology while keeping the developing countries under the US influence, required the development of a new orientation towards the Latin America. This policy would then act as a tool to maintain the US influence in the Latin American countries. The US policy makers of the time focused on interest and on the strengthening of the political ties between the US and the Latin America to guide this new orientation, in contrast with the prior attitude of detachment. The attitude of detachment had oriented US policy towards Latin America in the prior decades once the region was outside the Soviet Union zone of influence as well as outside the Cold War geographical context. Thus, during the period of 1947-1961, Latin America was not a priority to the US government [2].

This new US orientation towards the Latin America the Alliance for Progress - in the awake of the 1960s events resulted in the Americas being guided by four basic political pillars, in which freedom is at the core. Those pillars are: 1) the acknowledgment that genuine freedom requires economic and social welfare for all; 2) the principle of human freedom; 3) that American countries should not serve as tool or prisoners of foreigners political ideologies; 3) the principle that governments' legitimacy are conditioned upon their population's free political choice and that their political mandates may end without the need of the use of force. These Alliance for Progress pillars would guide both the US actions and discourse towards the Latin America from 1961 to 1969 [2].

This is the context in which political scientist Walt Whitman Rostow formulated the modernization theory. The theory became the theoretical foundation of the Alliance for Progress and shaped the ideology of the new policy. In addition to the political context, the theory also emerged within a broader social science movement, which relied on formalist theories of economic and political development, whose premise is that society development may be measurable according to universal standards.

Thus, according to Rabe [3]:

They fashioned the Alliance for Progress on contemporary social science theories, espoused by intellectuals, which included Ambassador Gordon and presidential assistant Walt W. Rostow. In the postwar period, social scientists had enunciated formal theories on political and economic development. They posited a universal, quantitatively measurable movement of all societies from a "traditional" situation toward a single ideal form or "modern" organization. Traditional societies, as they presumably existed in Latin America, had authoritarian political structures, rural, backward economies, and a lack of faith in scientific progress and the entrepreneurial spirit. A modern society that would resemble the United States would be characterized by a competitive political system, a commercialized and technologically sophisticated economic system, mass consumption, high literacy rates, and a geographically and socially mobile population.

Following this line of thought, Rostow argues that societies develop according to a maturity scale, in a similar fashion as human beings do [4]. Rostow [5] conceived modernization as the process by which institutions become prepared to promote social, economic and political change. In the author's view, institutions become prepared to foster change when the accumulated human knowledge of a society also reaches a certain development stage. Thus, institutions are a reflection of a society current state of human knowledge. Once both human knowledge and institutions accomplish development, control over the environment may be possible and social, economic, and political changes follow through. Rostow [5] therefore claimed that modernization simultaneously required and would lead to several changes in the economic organization, the social values systems, and the political structures of each society. Changes that, in the end, would reflect a society's development and maturity

\section{The role of the Modernization Theory in the Shaping of the 1960s Brazilian Public Policies for Economic, Social and Educational Development}

The implementation of the Alliance for Progress had the modernization theory influencing the shaping of the Brazilian educational, social, and economic public policies during the 1960s. Although the Alliance for Progress focused on Latin America as a whole, Brazil received special attention compared to its regional counterparts. Loureiro [6] argues that the Alliance for Progress' success depended on Brazil's compliance. There was the fear that in the face of Brazil's non-compliance it would result in a sort of "Latin America's China" due to the size of its territory, population and resources. As a result, the US government put greater effort in providing financial 
support to Brazil [6], which in turn resulted in a major influence on the Brazilian public policies.

This major influence on Brazil's public policies found its way by means of the requirements for social and cultural adaptation as conditions for obtainment of the financial support. Loureiro [6] claims that the Alliance required a substantial cultural and social adjustment in the path to modernization. In the case of Brazil, the recommendations for adjustment claimed for the need of a comprehensive educational reform. The lack of a work-oriented education resulted in the short supply of skilled labor, hampering industrial development as well as job creation.

In line with the modernization theory's core premise that societies develop and mature according to universal standards in spite of local particularities, the implementation of the American model of modernization in Brazil implied that the features of the industrial and technological civilization transcended political contexts [7]. In other words, the American model of modernization aimed for the cultural, social, political and economic homogenization of the globe. This modernization model based on the central role of the modern elite (in contrast with the conservative elite), on technological diffusion, and on the implementation of democratic capitalism as opposed to totalitarianism:

"The modernization theory is analogous to the American social modernism, to the New Deal liberal thought, which assumes a rational, benevolent and technocratic state, able to solve all social and economic problems. The Developmental State is the peripheral version of the Western industrial welfare states. Therefore, the theory is a discourse about the United States society of that time, an expression of the American values and ideas." [7]

At the same time, the rising of the military rule in Brazil (1964) accelerated and deepened the country's compliance with the modernizing mindset of the time. Romanelli [8] observes that the economic model the military regime adopted reassured the international discourse based on the economic, political, and consumer habits modernization according to the US model. Relying on the US financial support, the military regime fully adhered to the American-capitalist model.

Gaio [9] notes that the presence of the United States Agency for International Development (USAID) experts in Brazil marked the formulation of public policies during the 1960s. As a first step, the experts provided guidance, structure and promotion during the formulation process. Following that, the US financially supported the main educational development projects that would advance the modernization model in Brazil. Gaio [9] also argues that the agreements aiming to Brazil's educational development played a key role in the success of the economic development projects because:
“(...) they aimed to accomplish this new social mobility by means of the accumulation of individual human capital, as well as also promote the emergence of a significant number of trainable individuals whose capital and competition values are already internalized, always beyond the capacity of absorption of the job market" [9]

Theorists from a critical perspective have identified some of the consequences of the modernization model implementation for the Brazilian education. Saviani [10] named as "production-oriented education" the educational model that resulted from the USAID guidance, laid out in the Ministry of Education (MEC)-USAID agreements, since:

"[the MEC-USAID agreements] gained imposition power when incorporated into the educational legislation during the military rule, having rationality, efficiency and productivity as their principles, and based on the corollaries 'maximum productivity, minimum costs' and 'avoid duplicating effort'" [10]

Another critical theorist, Neto [11] argues that this "production-oriented education" results in the public use of education as a wealth tool but without addressing its unfair distribution as well as the resulting job hierarchy. In other words, this educational model reproduces the capitalist ideology and the social relations of this mode of production. This production- oriented education thus reflects the American-capitalist values imbued in the Alliance for Progress principles, backed up by the modernization theory. Moreover:

"The signing of the MEC-USAID agreements resulted in the law 5.540/68, which promoted the reform of the higher education, and in the law $5.692 / 71$, which resulted in the reform of the elementary and secondary school. Through these reforms, the state attributes to education the function of providing the needed development conditions for the success of its own political and economic project. Thus, the educational policies become central for the development of the industrial capitalist production. For this reason, the state adjusts the educational policy to their own needs, so as to integrate this policy to the national development project" [11]

In addition to the MEC-USAID agreements (enacted law n 5.540/68), the Alliance for Progress' influence on Brazil's education also resulted in additional agreements signed between the Brazilian states and the USAID as well as in other nineteen agreements signed between 1964-1972. These additional agreements focused on: 1) elementary school improvement; 2) high school enhancement program; 3) agricultural experts training; 4) modernization of university management; 5) technical, scientific and 
educational publications; 6) primary, secondary and higher education integration; 7) implementation of a new high school curricula; 8) technical assistance on the formulation of educational plans at the state level.

According to Romanelli [8]:

"It may not be imprudent to assert that the documents that shaped the Brazilian educational policy drew their core principles from the MEC-USAID agreements. In this manner, the agreements were no longer temporary, as explicitly stated in their text, but became permanent, establishing the grounds of our educational system" [8].

The influence of these educational policies formulated under the USAID guidance did not cease with the end of the military rule and the transition to a political democracy in the 1980s. In fact, there are more continuities to this non-linear historical unfolding of events than discontinuities, as Saviani [10] observes:

"The 'democratic transition' has been done, thus, with the elite's consent and aiming to maintain the socioeconomic order. An international scenario in which the market is at the center stage and the main authority is the financial capital has further strengthened this socioeconomic order since the beginning of the 1990s. Under such conditions, is not difficult to understand the constant claims for closing the links between education and the market, for a greater appreciation of the private sector with an emphasis on the adoption of managerial mechanisms in education administration, as well as the growing pressure on graduate education as a consequence of the increasing demands for productivity" [10]

\section{The Modernization Theory Updated: the Role of the Evaluative State in Today's Education}

As mentioned before, the modernization theory intended to shape the multiple dimensions of a society in the pursuit of social (evolutionary) change based on universal standards allegedly applicable to all contexts. These society's dimensions includes the social, the political, the economic, as well as the educational aspects. Since the theory has a comprehensive scope and embodies the core American-capitalist values (which became the predominant world ideology in the aftermath of the Cold War and the communist ideology decay), authors argue that the theory's core premises share similarities with the principles of today's mass education and of a common world educational culture [Meyer 1979 in 12,1,13]. For instance, Dale [12] highlights that, from an institutionalist perspective, it is expected that today's public institutions (and their public policies) from a wide range of countries, despite local specificities, should reflect a common worldview and follow universal standards:

“The institutionalists' core argument is that the nation-state institutions, and the state itself, must be conceived as being essentially molded at a supranational level according to the ideology of the predominant world (or the Western), and not as unique and autonomous national creations. In this perspective, the states have its activities and policies molded by universal norms and culture" [12]

Furthermore,

"The fast expansion of the national educational systems and the evident, but surprising, curricular homogeneity degree among the societies of the world, regardless of their geographical location, development level, and religion or any other traditions, cannot be explained by the functional, national, cultural or rational instrumental theories that have been prevailing in the study of educational systems or curricula since then. They derive, in the first place, from the modern statist model that expanded quickly since 1945". [12]

Afonso [1] also argues that the modernization theory's core ideas manifest in today's education. In the author's view, the modernization theory's premises relate to the current international assessment programs that evaluate students' performance across a wide range of national educational systems. Afonso [1] claims that this influence occurs mainly due to the modernization ideological dimension, which is constantly renewed and updated, in spite of its questionable scientific validity.

Thus, the American-capitalist ideology (also at the core of the modernization theory, as aforementioned) would be at the core of the Evaluative State model, which has been evolving since the rise and spreading of liberalism in the 1980s. Governments across the globe have been using standardized tests and rankings since then to support higher education investments. The Evaluative State model, created and initially employed in developed nations, such as the United States and the United Kingdom. Later on, the rise of globalization has resulted in the spreading of the Evaluative State model to developing nations. Global institutions, such as the International Monetary Fund (IMF), the Organization for Economic

Co-operation and Development (OECD), and the World Bank, played a key role in the adoption of such a model by developing countries, imposed as a condition for financial support.

The OECD may be the main international agency that reflects what Afonso [1] denominates as "the mobile epicenter" of the modernization theory nowadays. As the 
authoritative source on education in today's world, the agency and its standardized test PISA (Program for International Student Assessment) defined new leading actors and places in the educational field. The $\mathrm{PISA}^{3}$ is one of the main regulation tools in the educational domain nowadays.

For Afonso [1], the growing demand for international educational indicators and assessments by developing countries reflects the modernization theory's continuity. Thus:

"(...) some forms of comparative assessments (for example, the PISA) had spread worldwide because many peripheral and semi-peripheral countries continue to pursuit modernization goals, seduced by the prospect of progress (or of development), which are connected to the educational agenda of the central capitalist or highly developed countries (even though these agendas seem neutral or benevolent because they are advertised by prestigious international organizations such as the OECD). More specifically, it is the belief in the principles of the modernization theory and of the neomodernization (and on the demonstration-effect) that underlies this obsession with and the expansion of evaluation to which a significant number of countries of the world system adhere to, perhaps uncritically" [1]

We may conclude then that the 1960s modernization theory is still present in today's world, updated and revitalized. The modernization theory and the American-capitalist values that lie at its core may be the essence of what Afonso [1] names as the "Evaluative State". The Evaluative State model imposes standardized tests, homogenizing education across the globe supposedly to promote quality. The Evaluative model does so by using a two-way

According to the OECD, "[t]he Programme for International Student Assessment (PISA) is a triennial international survey which aims to evaluate education systems worldwide by testing the skills and knowledge of 15-year-old students. In 2015 over half a million students, representing 28 million 15 -year-olds in 72 countries and economies, took the internationally agreed two-hour test. Students were assessed in science, mathematics, reading, collaborative problem solving and financial literacy". The results of the assessment are published and countries are ranked based on their students' performance [14] mechanism: on one side, international organizations demand developing countries to adhere to standardized tests; on the other side, the governments of developing countries comply with these international educational assessments searching for political legitimacy and financial support.

The developing countries' compliance and achievement of "good results" on the standardized tests mean that these countries are "evolving and getting mature". In other words, these countries are in the "path to modernization" and the developed countries are the model to follow. Therefore, the modern civilization model that relies on the dismissal of the particularities of each people and culture and on the establishment of a single path to modernization perpetuates in today's world.

\section{Conclusions}

After exposure, analysis and comparison of theories we find, as research results, the strong presence of Modernization Theory in international educational programs, especially for those who focus on aid for Latin America. Brazil, when we analyze the Theory of Modernization, is included in this scenario by factors such as assessment that does not consider the local contexts and is applied from top to bottom, study material organized by international organizations and not by local teachers. Also, education privileges the formation of workers instead of human formation. All these were concepts preached by the Alliance for Progress that we can still see today in Brazilian and Latin American education.

The Alliance for Progress emerged during the Cold War out of the United States' need to counter the influence of the Soviet Union communism in Latin American. The Cuban Revolution in 1959 and the perceived risk of a communist ideology expansion were the triggers for what became a change of attitude from the United States towards Latin American.

As a comprehensive program, the Alliance for Progress also had its ideological component. The social science thinking of the time in the United States contributed for the Alliance for Progress' ideological component. The modernization theory, elaborated by Walt Whitman Rostow in 1960, reflected the American-capitalist values. This theory's core premise is that the modern nation model requires democracy as the form of political regime, consumption and production-oriented economy, universal literacy, and a socially and geographically relevant population. The ideal modernized nation model, thus, reflected the United States' society values of the time, and they would assist the developing countries in the path to modernization. Financial support and international technical assistance would provide the needed conditions to accomplish development.

The USAID provided assistance to countries that adhered to the Alliance for Progress. The agency's role included the provision of technical guidance, and in Brazil, this guidance resulted in the MEC-USAID educational agreements. These agreements encompassed key educational aspects, from technical needs such as the setup of libraries to teacher training in American universities.

The modernization theory may be outdated to some authors nowadays. However, Afonso [1] argues that the 
theory's core premises perpetuate in today's Evaluative State model. In the educational field, the Evaluative State employs international standardized tests and rankings to seek support and legitimacy to its educational policy. Developing countries across the globe must adapt to developed countries educational models, which in most cases do not take into consideration local particularities.

This adherence to a universal educational model may be the contemporary face of the modernization theory, which requires the developing countries' compliance to foreigner certifications, elaborated by developed countries. In this model, developing countries must adhere to universal educational culture and norms. Consequently, local particularities are set aside in the search for international approval - or for national modernization.

\section{REFERENCES}

[1] AFONSO, Almerindo Janela (2013). Mudanças no Estado-avaliador: comparativismo internacional e teoria da modernização revisitada. Revista Brasileira de Educação v. 18 n. 53, abr.-jun., 267-284. Online available: http://www.scielo.br/pdf/rbedu/v18n53/02.pdf. Access: 02 set. 2017. 276

[2] US GOVERNMENT (1961). Report from the Task Force on Immediate Latin American Problems to President-elect Kennedy. Foreign Relations of the United States, 19611963, Volume Xii, American Republics. Online available: https://history.state.gov/historicaldocuments/frus1961-63v 12/d2. Access: 31 may 2016.

[3] RABE, Stephen (2016). Alliance for Progress. Oxford Research Encyclopedias - Latin American History. Available in: http://latinamericanhistory.oxfordre.com/vie w/10.1093/acrefore/9780199366439.001.0001/acrefore-97 80199366439-e-95?rskey=JcggSu\&result=1. Access: 11 jul 2016

[4] LATHAM, Michael (2000). Modernization as Ideology American Social Science and "Nation Building" in the Kennedy Era. University of North Carolina Press.

[5] ROSTOW, W.W. (1960). The stages of economic growth: a non-communist manifesto. Cambridge: Cambridge University Press.

[6] LOUREIRO, Felipe Pereira (2013). Dois Pesos, Duas Medidas: Os Acordos Financeiros de 1961 entre Brasil e Estados Unidos durante os Governos Jânio Quadros e João
Goulart (1961-1962). Economia e Sociedade, 22(2), 547-576. Online available: http://www.scielo.br/pdf/ecos/v22n2/a09v22n2.pdf. Access: 17 may 2016.

[7] RIBEIRO, Ricardo Alaggio (2006). A Aliança para o Progresso e as Relações Brasil-Estados Unidos. Tese de Doutorado. Universidade Estadual de Campinas. Instituto de Filosofia e Ciências Humanas. Departamento de Ciência Política, 72-73. Online available:

http://repositorio.unicamp.br/bitstream/REPOSIP/280107/ 1/Ribeiro,\%20Ricardo\%2 0Alaggio.pdf. Access: 26 jun. 2017.

[8] ROMANELLI, Otaíza de Oliveira (2013). História da educação no Brasil. Petrópolis, RJ: Vozes.

[9] GAIO, Daniel Machado (2008). A concepção de modernização na política de cooperação técnica entre o MEC e a USAID. Programa de Pós-Graduação em Educação - Mestrado em Educação. Universidade de Brasília. Online available: http://repositorio.unb.br/bitstrea m/10482/2106/1/2008_DanielMachadoGaio.pdf. Access: 03 jul. 2017.

[10] SAVIANI, Dermeval. O legado educacional do regime militar. Cadernos Cedes, v. 28, n. 76, 2008. Online available:

http://www.scielo.br/pdf/ccedes/v28n76/a02v2876.pdf. Access: 03 jun. 2017. 297

[11] NETO, Álvaro Sobralino de Albuquerque (1995). Legislação e política educacional brasileira. Revista Brasileira de Estudos Pedagógicos. Brasília. v. 76, n. 184, p. 699-734, set./dez.Available online :

$<$ http://rbep.inep.gov.br/index.php/rbep/article/view/1111/ 1085 > . Access: 30 april 2015

[12] DALE, Roger (2004). Globalização e educação: demonstrando a existência de uma "cultura educacional mundial comum" ou localizando uma "agenda globalmente estruturada para a educação"? Educação \& Sociedade, Campinas: CEDES, v.25,87, 423-460. Online available: ht tp://www.scielo.br/pdf/es/v25n87/21464.pdf. Access: 25 set. 2017.

[13] SCHIMIDT, Volker H (2011). Modernidade e diversidade: reflexões sobre a controvérsia entre teoria da modernização e a teoria das múltiplas modernidades. Revista Sociedade e Estado, Brasília: Departamento de Sociologia da UnB, v. 26, 2, p. 155-183, .Online available: http://www.scielo.br/scielo.php?script=sci arttext\&pid=S0 102-69922011000200009.Access: 15 sep 2017.

[14] Organization for Economic Co-operation and Development (OECD) (2018). About: Programme for International Student Assessment. Online available: http://www.oecd.or g/pisa/aboutpisa/. 